\title{
FNTB Gene
}

National Cancer Institute

\section{Source}

National Cancer Institute. FNTB Gene. NCI Thesaurus. Code C38603.

This gene is involved in subcellular protein targeting and the post-translational

modification of certain proteins. 